\title{
Post-Traumatic Stress Disorder in the Yellow Birds: A Case-Study in the Light of Psychoanalytical Theories
}

\author{
Sunil Sagar' ${ }^{1}$, Maysoon Shehadah ${ }^{2}$ \\ ${ }^{1}$ Associate Professor \& Head, Department of Languages, Faculty of Arts and Humanities, Marwadi University, Rajkot, Gujarat, \\ India \\ ${ }^{2}$ PhD Scholar, Department of Languages, Faculty of Arts and Humanities, Marwadi University, Rajkot, Gujarat, India \\ Email: ${ }^{1 *}$ sunil.sagar@marwadieducation.edu.in, ${ }^{2}$ maysoon.shehadah106321@ marwadiuniversity.ac.in
}

\begin{abstract}
This study is a case study of post-traumatic stress disorder, caused by war. It digs into the unconscious area of the soldiers' minds and gives the findings according to psychoanalytical Theories. Though this study tackles characters in a novel which might be considered as fictional, these characters are sketched from real life as the soldier is an old veteran who has been fighting in the Iraqi war. The author, Kevin Powers depicts not only his sufferings in and after war, but he sheds light on the sufferings of his colleagues. The hero is diagnosed with PTSD upon his arrival to his homeland. The story is that of the soldier who has witnessed the horrors of wars and suffers terribly from it; he is the one who has felt the agony of grief and loss after witnessing the death and suicide of his friends due to melancholy. The psychoanalytical theories help elaborate on post-traumatic symptoms he suffers from. The protagonist is the mouthpiece of the writer who realizes the catastrophic aftermaths of war on both soldiers and civilians, psychologically speaking. The novel reveals the humanitarian side of the soldier who is forced to kill and make the audience sympathize with him.
\end{abstract}

Keywords

War, Post-Traumatic Stress, Psychoanalysis, Neurosis, soldier

\section{Introduction}

Though its symptoms appeared long time ago, "Post-Traumatic Stress Disorder" was not identified as a psychological illness and studied as a separate psychological disorder till the beginning of the last century in association with the First World War. Being associated with war, the term has got many names such as "shellshock", "combat fatigue" and "war neurosis". Modern psychoanalytical studies unveil the seriousness of this disorder and its diverse symptoms which vary from one person to another, and dwell on it.

As it was recognized in the soldiers of WWI, PTSD was called "shell-shock" in the beginning for its affinities with war aftermath when the soldiers, being exposed to shells, developed this disorder afterwards. It was called "combat fatigue" after WWII. However, it is not restricted to soldiers. Its intensity varies in people, and it might develop into "acute stress disorder".

After Vietnam War, PTSD replaced the previously known terms as "shell-shock", "war neurosis", and "combat fatigue", in the third edition of the Diagnostic and Statistical Manual of Mental Disorders published by the American Psychiatric
Association, 1980. (Crocq \& Crocq, March 2000, pp.47-55)

"Post-Traumatic Stress Disorder" is set by the American Psychiatric Association as:

Posttraumatic stress disorder (PTSD) is a psychiatric disorder that may occur in people who have experienced or witnessed a traumatic event such as a natural disaster, a serious accident, a terrorist act, war/combat, or rape or who have been threatened with death, sexual violence or serious injury. (PTSD, n.d.)

\section{Literature Review}

Since WWI, studies have been done on PTSD. However, it has been agreed that all of the infected people share one or more of these symptoms cited as follows:

People with PTSD have intense, disturbing thoughts and feelings related to their experience that last long after the traumatic event has ended. They may relive the event through flashbacks or nightmares; they may feel sadness, fear or anger; and they may feel detached or estranged from other people. People with PTSD may avoid situations or people that remind them of the traumatic event, and they may have strong negative reactions to something as ordinary as a loud noise or an accidental touch. (PTSD, n.d.) 
In fact, the psychological trauma of WWI stirred the founder of psychoanalysis, Sigmund Freud, to have a turning point in his studies. His book Beyond the Pleasure Principle is very important to this study as it argues for the first time about "death instinct" (Thanatos) which is the opposite of the "life instinct", (Eros). "Death in instinct, which is called "Thanatos" afterwards, means the destructive instinctual power in the ego. The two instincts, Eros and Thanatos, stand in sharp contrast to each other as the first one is identified by the sexual motives or life instincts that lead the human being into life, while the other is the destructive power inside the human that leads $\mathrm{him} /$ her into annihilation.

In the Fifth International Psycho-Analytic Congress symposium held at Budapest in 1918, Dr. S. Ferenczi, Dr. Karl Abraham, and Dr. Ernest Simme had a collection of articles turned later into a book introduced by Sigmund Freud and edited by Ernest Jones, PTSD associated with war was known as "war neurosis". Freud elaborates on the term in his introduction as:

The conflict takes place between the old ego of peace time and the new war-ego of the soldier, and it becomes acute as soon as the peace-ego is faced with danger of being killed through the risky undertakings of his newly formed parasitical double. Or one might put it, the old ego protects itself from the danger to life by flight into the traumatic neurosis in defending itself against the new ego which it recognizes as threatening its life; (Ferenczi et al, 1921, p.2)

The professors argue in the symposium that the disorder is ascribed also to the clash between the new ego and the old one as the human being should deny himself/ herself for the sake of the whole and should replace the taboos in his supperego with the new ideas tolerating murder, violence, and so on. They admit the role of psychoanalysis in analyzing the causes of the "war neurosis" and finding solutions to it.

In "Psychoanalytic Considerations on PostTraumatic Stress Disorder", the Emeries traces the development of psychoanalytical theories till 1989. The outcomes they introduce are the summary of the psychoanalytical theories till their time:
As psychoanalytic theory evolved, assumptions were made regarding the conceptualization of the traumatic process. It has included propositions relating to the principle of repetition compulsion (Freud, 1955a), helplessness (Freud, 1959, 138), surrender (Krystal, 92), intrusion and denial (Horowitz, p.7), the individual meaning of traumatic experiences (Green, Wilson and Lindy, 1985, p. 53), and traumatic disorders of the self (Parson, 1984). (1989, p.40)

The PTSD varies among people according to five criteria: "These are: a) nature of the stressor, b) the reexperiencing phenomena, c) avoidance or numbing behavior, d) hyperarousal phenomena and e) duration of the disturbance." (Emery \& Emery, 1989, p.41)

Consequently, the cause of the disorder, the repetition of the trauma, the mental status of the person and its content, the psychological emphasis on the external world, and the time of exposure to the pressure or the cause of the trauma identify its severity.

Anna Freud, following her senior psychoanalysts, ascribe the development of PTSD in some individuals rather than others, who face the same pressure or shock, to the development of "infantile stages" which her father, Sigmund Freud, explains thoroughly. In her "psychoanalytic study of the child", Anna says:

It is the essence of this view that the onset of mental disturbance, and especially of neurotic disorder, is due to conflicting forces within the personality; that it is nonspecific, i.e., that it has multiple causes, and that it can be located in all phases of development" (1983, p.383)

She clarifies the libido role in the trauma which means the role of the relations of the objects to the self.

Anna Freud's books are of crucial importance to this study. Her book The Ego and the Mechanisms of Defence analyzes the ten methods of the mechanism of defense that the troublesome ego resorts to in order to relieve the anxiety and the sense of guilt. It is the result of the conflict inside the ego. It is crucial for this study as the protagonist uses three of these mechanisms of defense due to his inner conflicts that end with PTSD. Anna Freud explains this conflict as: 
[The ego] defends itself no less energetically and actively against the affects associated with these instinctual impulses... Love, longing, jealousy, mortification, pain, and mourning accompany sexual wishes; hatred, anger, and rage accompany the impulses of aggression; if the instinctual demands with which they are associated are to be warded off, these affects must submit to all the various measures to which the ego resorts in its efforts to master them, i.e., they must undergo a metamorphosis. (1936/ 1993, p.32)

The mechanisms of defense that Anna Freud introduces are: "regression, repression, reaction formation, isolation, undoing, projection, introjection, turning against the self and reversal"; there is also an additional one which is "sublimation, or displacement of instinctual aims" (p.42). The last one contains the arts and creativity through which the human deflates the tension before it turns into "neurosis". Yet, "isolation" is "the mode of defense adopted in symptom formation by the ego of the obsessional neurotic" (p.35).

Psychoanalytic Understanding of Violence and Suicide, edited and introduced by Rosine Jozef Perelberg, is important also and included in this study as there are cases of aggression and suicide. In the editor's introduction to the book, murderousness and suicide are justified according to the following basis:

A. H. Williams points out the role of the 'traumatic experience' which remains undigested (1984) and stresses the importance of feelings of guilt for the therapeutic outcome. This includes depressive anxiety about the damage inflicted in reality or phantasy against the object. When the pathway is opened for depressive anxiety to be experienced, it is also opened for favourable developments (1984, p.1064). In 1995 A. H. Williams related murderousness to a failure to emotionally metabolise "problems to do with death'. The massive projection of these result in homicide or, if there is massive introjection, in suicide. (1999, p.20)

In his book, Psychologiat al-Huroob and Dawr al-Ilaj al-Nafsi, Idtirab Doughout ma baadal-

Sadma (the psychology of war and the role of psychotherapy in PTD), the Lebanese researcher in psychology Ghassan Yacoub adds "genes" to be among the factors that define the vulnerability of the human being and the trauma's severity. He elucidates that people get affected differently to the war trauma and even some of them never develop any disorder. The genes of the human being and his childhood are the great effects that determine his vulnerability to the trauma. The symptoms defined by Dr. Yakoub involve: "the form of physical and psychological symptoms (avoidance, dullness, troublesome images and thoughts, insomnia and sleep disorder, sweating, startling, fear, caution, weakness of memory and concentration,"i (1999, p.37) These symptoms were shown in the soldiers coming from the war of Vietnam. The main symptom that indicates PTSD is "avoidance", which means that the patient tries to avoid everything related to the trauma, be it a place, time, people or even feelings. Dr. Yacoub speaks also about "survivor's complex" which is seen clearly in the soldier's PTSD of this study.

In a study of PTSD on the same novel, i.e., The Yellow Birds, Faizal Yusuf Satriawan and Mundi Rahaya tackle the main hero's trauma according to Gerald Davison's theories of trauma issued in 2006. The writers ascribe John Bartle's PTSD to the destruction and loss he suffers from in the Iraqi War. The symptoms they talk about are "avoidance" which is the same as "denial" or "undoing" and "re-experiencing" as he recalls the events when he comes back from war. The study depends on the psychologist, Gerald Davison's studies of PTSD. It marks the death of Murphy as the main cause of trauma. But it does not refer to the other theories of psychoanalysis, nor it traces the status before the war as in the infantile development which the psychoanalytical theories depend on to find the reason of trauma in the "fixation" or childhood experience. It also does not trace the PTSD of war in other characters rather than the hero, John Bartle.

There is another important study on this novel published Gema Online Journal of Language Studies, 2020. It is entitled "Survival Psychology in Kevin Power's The Yellow Birds. The study dwells on the two main characters, i.e., John Bartle and Daniel Murphy in the three periods of "pre-impact, impact and post-impact". The study dwells on the main events that lead to the soldiers' trauma upon their arrival to fight in Iraq. 
However, this study is an extension of the former ones; and it tackles other psychoanalytical theories and deal with four characters in the novel and trace the trauma's effects on them from a psychoanalytical perspective. So, it probes the far reason of their vulnerability and the PTSD they show as well as mechanism of defense in response. These are John Bartle, Daniel Murphy, and Sgt. Sterling.

\section{Methods \& Methodology}

This study is a case study of PTSD development on characters representing real life. It is an observational and analytical study. It depends on secondary data analysis of the veteran narrative according to psychoanalytical theories introduced in this study. The study is descriptive in some places and analytical in others. It is an applied research that traces the development of the traumatic disorder in the characters.

This research is a qualitative one that gets the results through exploration of the findings on the novel. It depends on "Literary Criticism" as the text defines itself in applying the psychanalytical theories findings to trace trauma in the characters and it.

The data-analysis is done through the characters' speech and stream of consciousness. It deduces the results of PTSD through whatever the characters say, behave or reveal something in the stream-of-consciousness technique and interior monologues. Actually, these are best ways to get into the unconscious mind of the person. Though it is written according to the consciousness of the main character, John Bartle, who is the mouthpiece of the writer, the dilemmas of other characters can be deduced through this narrative. We can also get into the psyches of the other characters by analysing their speech and behaviour

\section{Discussion \& Findings:}

This study applies the psychoanalytical theories introduced in the literature survey on the main characters of the novel, The Yellow Birds, to trace PTSD as an outcome of war. The novel is a real life representative, written by the American veteran Kevin Powers, who finds deflation of the tension in answering the question of the Iraqi war through writing, i. e., sublimation or displacement of the instinctual aims haunted by neurosis and trauma developed in the war. The novel is a document of the terrible war, launched by the American Army on Iraq, written by the soldier who records his feelings as a human being in addition to his friends'; his sufferings reflect those of every soldier in every war.

The novel depends highly on stream-ofconsciousness technique of the protagonist, John Bartle. It is the technique associated with the twentieth-century novel to reveal the character's inner thoughts and feelings as a way to analyse it psychologically:

[W]hile the emergence of the stream-ofconsciousness novel in the twentieth century has to be related to the development of modern psychology and the increasing interest in the mental operations that accompanies it. (Hawthorne, 2017, p.119)

The writer, Kevin Powers, himself admits that in his acknowledgement as: "The book was primarily written alone" (Powers, 2012/2013, p.229). In answers to questions in a conversation with him and in his commentaries on the novel which are included at the end of the book, Powers elaborates on the process of deflating the tension through writing that relies on a stream-ofconsciousness technique:

In retrying to demonstrate Bartle's mental state, I felt very strongly that the language would have be prominent. Language, at its essence, a set of noises and signs that represent what is happening inside our heads... I tried with what little skill I have to create the cartography of one man's consciousness, to let it stand, however briefly, as my reminder." (p.238)

He gives a stereotype of as soldier who feels that "[h] is conflict is between his desire to redeem that failure and his acceptance of compete powerlessness." (p.239).

Indeed, the conflict in the ego leads us back to the essence of war PTSD which S. Freud argues about in his marking book Beyond the Pleasure Principle as "war neurosis' (in so far as the term implies something more than a reference to the circumstances of the illness' onset) may very well be traumatic neuroses which have been facilitated by a conflict in the ego." In his words, the neurosis stands as "a consequence of an extensive breach being made in the protective shield against 
stimuli." (1920/ 2015, p.26) It is what Dr. S. Ferenczi justifies in his paper for the conference as "these disturbances are not the direct effects of the trauma, but psychical reactions to it and act in the service of the instinct of self-preservation against the repetition of the unpleasant occurrence". He compares the symptoms of neurosis to those happening in fainting when the conscious mind tries to escape repression, tension and exhaustion, and "one is reminded by them of certain animals which simulate being dead when danger threatens." (Frenczi et al, 1921, p.12).

Though the novel is written in a flashback memory technique that covers a span of time of more than five years, from December 2003 upon the soldiers' preparation to go to Iraq till April 2009 when Burtle was released from prison and cured from PTSD, reader finds no coherence, nor any chronology in the recitation. The time passes according to the stream-of-consciousness of the main character. It passes psychologically with whatever the narrator remembers or imagines. It is that narration which brings us back to Virginia Wolf's writings, especially To the Lighthouse, which is also a war depicting novel. There is also no clear distinction between memory and imagination. The troubled mind of the soldier interrelates events seen, witnessed or even imagined with each other. This creates bewilderment in the readers' minds to decipher the events associated with the main plot. The plot is simple but the narration matters most as it is flowing from the fragmented psyche of the soldier.

The novel opens when the soldiers were in AlTafar, Iraq in September 2004, then the following chapter is sketched from New Jersey in 2003 before going to Iraq, afterwards the setting is shifted to Germany on return journey in 2005, then it goes back to Al-Tafar in 2004, then to Virginia 2005, and returns to Al-Tafar 2004, and keeps transferring till between years 2004 and 2005 and the hero's locations in Iraq and America. Suddenly, the last chapter moves to the year 2009 crossing around four years abruptly. That is why it is a typical psychological novel that has no chronology, full of haziness and troublesome memory of the soldier exhausted from trauma. Sometimes, the events are intermingling of memories and imagination. For example, Sergeant Sterling appears in a bar in Germany with Private
Bartle on the way home in chapter three, whereas in another scene in chapter nine, it seems that he shoots himself and dies. There is no clear implication about being imaginative or real:

I closed my eyes. When I closed them I saw Sergeant Sterling on the side of a mountain. Saw the rifle barrel in his mouth. Saw the way he went limp, so limp in that impossible moment when the small bullet emerged from his head. Saw his body slide a few feet down the mountain, the worn soles of his boots coming to rest in a clot of a pine needles. Then I opened them. (p.188)

He recalls this scene or imagining it in Virginia, when the C.I.D investigators question him. The question is: did Sterling commit suicide, or was he killed by Bartle's mind only to feel relieved from his painful memory?

In fact, Bartle's mind is heavy with troublesome memories and Sgt. Sterling is one of it. He might be one of the reasons leading to Murph's suicide and Bartle's PTSD and self-flagellation. How would the veteran forget the officer's cruelty, filthy words, torture and even orders to lie upon Murph's death that would lead to Bartle's imprisonment?

Dr. Ernst Simmel dwells on the role of the previously neurotic officers in the PTSD of the soldiers as:

For instance, a man after being wounded several times has to return to the front, or is separated from important events in his family for an indefinite time,...and, not least of all, his selfrespect is sorely tried by unjust and cruel superiors who are themselves dominated by complexes, yet he has to remain calm and mutely allow himself to be overwhelmed by the fact that he has no individual value, but is merely one unimportant unit of the whole.( Frenczi et al, 1921, p.32)

In tracing the aggressive behaviour of Sgt. Sterling, Dr. Simmel's study should be recalled. The aggressiveness and developed psychopathy shown by him indicates the deep psychological disturbance he suffers from. In fact, Sterling stands a sample of the military officers who show highly developed neurosis in their personae and who are relied on in war times to train the soldiers to be aggressive to enemy and never show regret. The officer's cases are discussed in the following 
quotation by Dr. Simmel presented in the same paper of the symposium, 1921:

It is now explicable why the war neurosis of the officer does not generally exhibit such gross symptoms as that of the ordinary soldier. The officer has raised himself above the crowd, and, with a higher mental development, has more possibilities of individually sublimating his own particular injuries. Nevertheless, the neuroses in officers will claim our psycho-therapeutic treatment in a far higher degree as soon as our colleagues agree not to look upon them from moral standpoints and to consider their comrades of the officer class under the courtesy diagnoses of Neurasthenia, Ischia, Neuralgia, etc. (p.32)

Sterling's behaviour and aggression cannot be traced to the infantile development in this paper as nothing has been explained about him except that he fought previously in Kuwait upon the Iraqi invasion. So, he is an experienced veteran who has a history of training and serving in the army. His disorder and psychopathy can be deduced from his filthy words' such as "motherfuckers", his senselessness to his soldiers' dilemmas, his mockery of Bartle's feelings towards his friend Murph, and his aggressiveness with the innocent civilian in Iraq. This can be analysed on the basis of S. Freud's study of "death instinct", the instinct that leads to destruction in every human being. It can be justified as a regression to the tendency of repetition that is shown in the children's games, as "the child passes over from the passivity of the game, he hands on the disagreeable experience to one of his playmates and in this way revenges himself on a substitute." It is the projection of the painful experience or suppression he suffers from on the others as:

here is a tendency to treat [internal excitations as though they we were acting not from the inside, but from the outside, so that it may be possible to bring the shield against stimuli into operation as a means of defence against them. This is the origin of projection, which is destined to play such a large part in the causation of pathological process. (S. Freud, 1920/ 2015, pp.23-26)"

S. Freud refers to "death instinct" as the "inanimate things existed before living ones". Its powers are destructive, but it turns into disorder when there is a clash between them. This clash drives some people into aggressiveness; others into self-destruction, i. e., suicide. In Sterling's case, there is a developed case of psychopathy as he feels no regret for his over-aggressiveness. His treatment of the bar girl reveals his deeply aggressive and sadistic nature though girl is a delicate human. When Bartle enters the bar, he notices that "[h]er skin was pale and freckled, and a deep, purple bruise welled beneath her right eye." (Powers, 2012/ 2013, p.64) He knows everything when Sterling comes in as he beats and insults her harshly:

"Huh, bitch? Not tonight?" He grabbed her by the face with his free hand and squeezed and she struggled to get loose and I could see on her cheeks a deep red where he held her. His thumb and fingers made the skin of each opposing cheek sink between her teeth, and she tried to pull away. (Powers, 2012/ 2013, p.66)

Yet, his sadistic nature can be traced in S. Freud's account of child's development:

During the oral stage of organization of the libido, the act of obtaining erotic mystery over an object coincides with that object's destruction; later, the sadistic instinct separates off, and finally, at the stage of genital primacy, it takes on, for the purpose of reproduction. It might indeed be said that the sadism which has been forced out of the ego has pointed the way for the way for the libidinal components of the sexual instinct, and that these follow after it to the object. Wherever the original sadism has undergone no mitigation or intermixture, we find the familiar ambivalence of love and hate in erotic life. (pp.46-47)

In his introduction to the book, Psychoanalytic Understanding of Violence and Suicide, Rozine Jozef Perelberg explains two types of aggression that Glasser distinguishes between them; "selfpreservation violence" and "sadism". "In selfpreservative violence the aim is to negate the danger and to remove the source of danger", but "in sadism (malicious violence) the aim is to take pleasure in inflicting physical and emotional suffering on another person." It is "an object relationship." (1999, p.4)

In fact, aggression is the result of a disorder in the "object relationship" and it has many reasons as is discussed in Perelberg's literature survey of psychoanalytical theories. It can be "an experience of danger, such as breaks in attunement", 
"impingement", "negative affective experiences", or "a defence against threats to the psychological self, or "reactive". Kohut says that "aggression is related to the experience of empathic failure" whereas "Fairbairn (1990) viewed aggression as a result of the infant's deprivation and lack of gratification". (1999, p.15)

This explanation justifies the aggression and sadism among human beings on the basis of infantile development, lack of love, danger or the terrible experiences and threats they face, especially in war. That is why some people become vulnerable, while others might suffer less or have no trauma.

Regardless of the war environments and aggressiveness which creates a split in the innerself, there is a "fixation" in a stage of development. Sterling is the officer who develops high degrees of not only "neurosis" but deep psychological disorders. And if he commits suicide in the novel, it can be justified according with his inability to reconcile with himself, and inability to love himself as he suffers from lovedenial at early stages. The destructive powers in his ego would lead to self-destruction as the hate would turn into the self itself to end up in a suicide. (p.31)

Turning to the two young soldiers, John Bartle and Daniel Murphy who join the army in an early age, the war trauma can be traced in both of their personalities. Yet, PTSD accelerates in Murph more than Bartle and brings about his death. However, the tragedy of the two soldiers is allegorized in the opening of the novel with the traditional U.S. Army Marching Cadence that explains how a fresh yellow bird is entrapped to be killed afterwards. The clue of trauma is stated in the narrators first line "The war tried to kill us in the spring." (Powers, 2012/ 2013, p.3). It is the psychological killing that the war does for the soldiers in their youth.

Bartle's vulnerability can be explained on account his childhood. Even in his adulthood, he has been the target of people's mockery and bullying. He justifies his choice to join the army as a trial to assert himself and prove his manhood to his environment and to his friends who used to accuse him of cowardice as appears in John's interior monologue:
... [B]ut then you signed up to go so it's all your fault, really, because you went on purpose, ... really, cowardice got you into this mess because you wanted to be a man and people made fun of you and pushed you around the cafeteria and the hallways in high school because you liked to read books and poems sometimes and they'd call you fag and really deep down you know you went because you wanted to be a man... (p.145)

On the other hand, nothing is known about the childhood of Murph, as the reader gets to know him by the narration of his friend, Bartle; yet his fragility and vulnerability can be deduced clearly from his behavior, speech and early death, and from Bartle's narration. He is the one who cannot stand the intolerable situation and the escapist who cannot confront catastrophes or sufferings. His mother asks Bartle to take care of him and to "bring him home" to her, and the later promises her to do hastily without thinking about the possibility of the issue. (p.47) Yet, this careless promise would cause Bartle a lot of sufferings later on as he promises for something, he has no control over, as he realizes afterwards.

The two young soldiers have to face the horrors and calamities of war with daily deaths and casualties among their comrades and among civilians; yet, they would pretend to continue as if nothing happened.

First, they witness the death of Malik, the Iraqi translator, their comrade as they "had his blood on both of [their] uniforms." With the first sense of sadness Murph asks Bartle to reassure him that it does not count. (p.11) They also witness the war burning the plants, the animals, the children, and even the old people; yet the soldiers have to obey the orders and fire:

He couldn't see them. I'll yell, I thought. I'll tell him they are old. Let them pass.

But bullets bit at the crumbling road around the car. They punched into the sheet metal.

I said nothing. I followed the car with my scope. The old woman ran her fingers along string of pale beads. Her eyes were closed.

I couldn't breathe...

The path they made was marked in blood: from the car smoking and blaze, through a courtyard ringed by hyacinths, to the place where the 
woman lay dead, attended by the small child, who rocked and moved her lips, perhaps singing some desert elegy I couldn't hear. (pp.22-23)

This description made by the narrator of the humanitarian catastrophes of war reveal the feelings of remorse for the innocent civilians and pricks of conscience. He elaborates on the massacres made by the army and the burning of plantation with a compassionate tone that has a deep regret in it. One of the most painful description of the soldiers' sufferings is revealed as follows:

I listened for an all clear but heard nothing. This is my life again. Fuck it, I'm not going to die in a grave dug by my own bleeding hands. I got up as I rose to my knees the mortars began to fall again, though not so close as before... I was afraid. My eyes welled with tears, and I wet my pants and though there was no need I shouted "I'm up" ... (p.168)

These atrocities and sufferings have to be justified on the account of noble reasons of justice and goodness by the superiors to avoid self-blame on parts of the soldiers and to motivate them to go ahead with their missions:

"Boys", he began, "you will soon be asked to do great violence in the cause of good." ... "I know I don't have to tell you what kind of enemy you'll be up against." His voice became a blunt staccato as he gained confidence in his capacity to motivate us, a bludgeon that soothed the weary creases in my brain. "This is the land where Jonah is buried, where he begged for God's justice to come." He continued, "We are that justice..." (87)

The colonel previous accounts lead us to the the cause of "neurosis"; i.e., the clash of the old and new super egos clarified by Ernest Jones:

The manhood of a nation is in war not only allowed, but encouraged and ordered to indulge in behaviour of a kind that is throughout abhorrent to the civilised mind, to commit deeds and witness sights that are profoundly revolting to our æsthetic and moral disposition. All sorts of previously forbidden and buried impulses, cruel, sadistic, murderous and so on, are stirred to greater activity, and the old intrapsychical conflicts, which, according to Freud, are the essential cause of all neurotic disorders, and which had been dealt with before by means of "repression" of one side of the conflict, are now reinforced, and the person compelled to deal with them afresh under totally different circumstances. (Frenczi et al, 1921, p.46)

This is expressed clearly by Bartle upon his return. He even gets astonished by the intimacy and welcome shown by his people, and the feelings of pride and admiration they reveal to the soldiers, among which is his own mother who is his model in life, the one who teaches him the morals and taboos on a humanitarian basis; whereas he thinks that they should feel "ashamed" of their atrocities:

Or should I have said I wanted to die, not in the sense of wanting to throw myself off that train bridge over there, but more like wanting to be asleep forever because there isn't any making up, or for that matter killing men and shooting them in the back and shooting them more times than necessary to actually kill them and it was just like trying to kill everything you saw sometimes because it felt like there was acid seeping down into your soul and then your soul is gone and knowing from being taught your whole life that there is no making up for what you are doing, you are taught that your whole life, but then even your mother is so happy and proud.... (Powers, 2012/ 2013, 144)

Obviously, the clash happens inside every soldier between whatever morals he has learnt and whatever murders he is to commit, which stand in sharp contrast to each other.

These atrocities and the senses of guilt and remorse create a "survivor's complex" inside John Bartle that can be deduced clearly from his speech in the previous quotation. Dr. Yakoub has marked some cases of PTSD to be associated of what he calls "unification with the dead" or "survivor's complex" that was developed by the survivors from the nuclear attack in Japan, as the person feels guilty for being alive while other family members or friends have died. He depends on the studies of the American psychiatrist Robert Jay Lifton on the aftermath of Japan nuclear disaster (Yakoub, 1999, pp.20 - 21). These signs of complexes are reflections of PTSD that John Bartle suffers from. These feelings of shame and guilt, that add to his disorder, get worse upon his friend, Murphy's death and his failure to keep his promise to his mother. 
In fact, Bartle has done his best to save Murphy, but the latter is exposed to a destructive trauma that would lead to his hysterical behaviour and subsequent surrendering to the enemy fighters in a suicidal act.

As it has been discussed earlier, there is nothing known to us about Murph's childhood to tackle the far reason of his fragility and vulnerability; but it is clear that he is the sensitive and tender person who would escape the pressure and attempt to overcome the war horrors by the power of love and humanitarianism.

First, Murph, as the others, suffers from humiliation, witnesses the war atrocities and lives from pressure as Bartle. Yet, the later has a noble reason to stay stand, that is to keep his promise to his friend's mother and to bring him home alive. But Murph suffers from "love denial" in a form of letter from his girl-friend claiming to break up with him. The sadness of Murph is shown by Bartle's explanation:

It makes me love him a little, even now, to remember him sitting beneath the hawthorn tree, sad that his girl had left him, but without anger or resentment, despite being only a few hours removed from all the killing the night before. $\mathrm{He}$ sat there in the dark... There was an expression on his face that I have never seen before or since. (Powers 2012/ 2013, pp.80-81)

Murph is the one who keeps his sufferings inside and tries to defend them by "repression". The sense of "self under-estimation" and "inferiority complex" is expressed in his own words about his ex-girlfriend: "I can't say I blame her. Too smart to stick with me." (p.81)

S. Freud asserts that "sexual instinct", which has the wide connotations of "life instinct" in his explanation, is the instinct that is responsible for prolonging the human lives. Yet, the loss of love leads into disturbance as he elaborates:

Loss of love and failure leave behind them a permanent injury to self-regard in the form of a narcissistic scar, which in my opinion, as well as in Marcinowski's (1918), contributes more than anything to the 'sense of inferiority' which is so common in neurotics. (1920/ 2015, pp.14-15)

The catastrophes he witnesses, his pricks of conscience, and the loss of love lead Murph to another way to escape his sorrow. He retreats to the world of humanitarianism and love and tries to avoid even his close friend that ties him with the war setting.

Bartle becomes worried as he never sees Murph for days. He tries to search for him and find out the reason behind his "avoidance" and "retreat" mechanisms. Murph finds his compensation in the medic's station with another love affair with the tender and humanitarian nurse:

And I thought it was this and not her beauty that brought Murph there over those long indistinguishable days. That place, those little tents at the top of the hill, the small area where she was, it might have been the last habitant for gentleness and kindness that we'd ever know... For sure, Murph wanted to see something kind, he wanted to look at a beautiful girl, he wanted to find a place where compassion still happened, but that wasn't really it. (p.165)

Murph needs the compassion to fill in the cracks in his psyche and help him to recover from the PTSD caused by war and loss: "He wanted to have one memory he'd made of his own volition to balance out the shattered remnants of everything he hadn't asked for." (p.165)

Consequently, he is driven crazy by the death of the girl in the medic's center. Nothing could console him. "The narcissistic security gives way to a feeling of powerlessness and the neurosis sets in". The young man has got what is called "traumatic hysteria" (Frenczi et al, 1921, p.25) This is shown in his behaviour and ultimate suicide:

From the train tracks that edged the outpost, a foreign boy walked naked, his shape lacking all color except for where his hands and face were tanned to a deep brown by the sun. He walked as a ghost, his feet and legs bleeding from his walk through the wire and detritus. (Powers, 2012/ 2013, 195)

He walks towards death and looks at the sky. It is most apparent to be an act of suicide to submit himself nakedly to the fighters of the other side to get killed, when the man cannot do that himself. PTSD leads Murph to death and this case can be traced in S. Freud's paper "Mourning and Melancholia", 1917, "that after a loss or a 'real slight or disappointment' coming from a person 
for whom there are strong ambivalent feelings, the hate originally felt toward the person may be redirected toward a part of the self now identified with the person." (Perelberg, 1999, p.63). So, the destructive powers in the ego turns against the self in Murph's situation.

Consequently, John Bartle feels underestimation of the self after his failure to keep his promise to Murph's mother. His grief and sorrow are as deep as his sufferings, psychologically speaking. His PTSD increases after witnessing the horrible atrocities of war and the loss of his friend. Thinking of his mother he agrees with Sterling to hide the truth of Murph's death and to throw his body in the river. He feels himself not worthy of living, as has been elucidated before, as he gets "survivor's complex". The atrocities and murders committed by the army against the civilians add to his underestimation of the self and feeling of guilt.

The first mechanism that John inclines to is "undoing". He lies to everybody, among them Murph's mother. Moreover, he writes a letter to her on her son's behalf as if he was still alive and trying to soothe her worries. This lie would add to John's torture and leads him to prison by the authority upon his arrival.

The same mechanism of defence would be shown by Mrs. Murphy as she believes the lie even though she should have known and realized that the letter is not written by her son despite of the efforts that Bartle makes to make it seems like those of Murph's: "She must have taken those glances with an unusual skepticism of a rural mail carrier as experienced as she was, ... She'd take the letter in both hands and become briefly, terrifyingly happy." (Powers, 2012/ 2013, p.31). In fact, she is the mother and can sense the change by her intuition; yet she wants to believe that her son is good and healthy. This is a "denial" to believe in what she does not wish to occur. Thus, she waits for her son's arrival from war.

Bartle writes the letter ten months after Murph's death and his own grief has been growing. This letter does not make him relieved. His psychic split is expressed by him:

Ten months, give or take, from that day to the day he died. It might seem like a short time, but my whole life since has merely been a digression from those days, which now hang over me like a quarrel that will never be resolved. (p.30)

The "denial" of Murph's death in the conscious mind and his "avoidance" to approach it or speak about might bring an apparent relief to himself as a mechanism of defence. Even when Sterling tries to recall Murph's accident, Bartle denies that he remembers anything of the accident. He couldn't even confess his sins and guilts to the priest. Yet, the memory still haunts him: "When I try to put it out of my mind, it only comes faster and with more force." (p.61)

He suffers from melancholy, isolation and selfflagellation after coming back home due to the crimes he has witnessed, the mistreatment of his superiors, and his failure to save his friend. He feels himself as the others, a number that is added to the total account of the war. Of the most expressive details that reveal war's horrors in the soldier's own words and the PTSD he suffers from is the following quotation:

I listened for an all clear but heard nothing. This is my life again, I thought. Fuck it, I'm not going to die in a grave dug by my own bleeding hands. I got up as I rose to my knees the mortars began to fall again, though not so close as before. An adjustment of fire. No one was around to call out direction or distance, so I ran. I was afraid. My eyes welled with tears, and I wet my pants and though there was no need I shouted "I'm up" and took off on limbs of unset jelly. (Powers, 2012/ 2013, p.168)

He becomes alcohol addicted. He drinks heavily in an action to forget. This is noticed in the German bar on his way home: "I was quite drunk and my head was foggy. I went behind the bar and found a whisky bottle. I sat on the floor and drank the rest of the whisky." (p.71) Even when he isolates himself upon returning from war, he would only go out to bring a drink or potpies.

Bartle tries to forget everything happened to him by "denial" and "repression". He even assures that everything is okey with him to his own mother: "I'm fine, Momma. Everything is fine." (p.148) though he is diagnosed with PTSD and "overly stressed" by a test made on him in Kuwait upon his return. (pp. 184-185). The torture and stress are kept inside him and come in the form of nightmares as usually happen in PTSD cases. 
Bartle isolates himself and he even leaves his mother's house. He does not speak with any one even his friends who tries to call him and meet feeling proud that he is a soldier, yet "recurrence" of memory, self-flagellation and nightmares will never leave him safe:

Late August. I left my mother's house. I'd developed the habit of taking long, aimless walks to fill the days. I woke one morning in a small room off the kitchen in my single bed wishing that I hadn't. It wasn't the first time. I was tired of my mind running all night through the things I remembered, then through things I did not remember for which I blamed myself on account of the sheer vividness of scenes that looped on the red-green linings of my closed eyelids. (p.135)

These dreams are justified by $\mathrm{S}$. Freud to be "endeavouring to master the stimulus retrospectively, by developing the anxiety whose omission was the cause of the traumatic neurosis." The "punishment dreams" are set as "they merely replace the forbidden wish-fulfilment by the appropriate punishment of it; that is to say, they fulfil the wish of the sense of guilt which is the reaction to the repudiated impulse." (p.26)

Yet, Bartle himself gets confused as he couldn't differentiate between what is real and what his ill mind invents. As it has been clarified earlier that the narration is that of a confused mind that there is no clear border between reality and imagination: "I could not tell what was true and what I had invented" (Powers, 2012/ 2013, p.135)

Afterwards, John Bartle would be imprisoned on account of his lying about Murph's destiny. Yet, he keeps suffering from severe PTSD in prison. Only writing could help him overcome these disorders as he "developed the habit of making a mark on a cell wall when [he] remembered a particular event" (216). This behaviour of "displacement" through writing has done him a great favour in recovering and reaccommodating with reality. There is no account of treatment of him in his imprisonment except through these remarks that fill the walls of his cells. When Bartle is released, he says farewell to his memories and kisses Sterling and Murph's memories goodbye.

\section{Conclusion}

In short, the novel is a "sublimation" of the soldiers' trauma. The novelist skillfully gives the humanistic dimension drawn upon his own experience with real or imagined characters sketched from real life. This study is a case study that epitomizes the PTSD of war on different samples of people. It digs into the tragedies of the soldiers that live the atrocities of war and become forced to commit murders. It reveals how the characters develop PTSD due to war. We face cases of aggression, neurosis, and suicide in the novel and severe symptoms of PTSD in the narrator's case. Those characters stand as examples of real-life people.

\section{Limitations and Future Studies}

This study can be applied to any other similar case as human beings are alike in their emotions, sufferings, love of life, hate of guilt, with little differences. It is a call to treat people according on the humanitarian basis and to understand their sufferings, psychologically speaking, and the reasons behind their aggressiveness. It is a call to help them to recover rather than punishing them. Th study would open the door for other coming studies which will dig more in the psychological trauma of similar cases in life or in literature and introduce solutions of treatment for similar cases.

\section{References}

[1] Alosman, M. I. (February 2020). Survival Psychology in Kevin Powers' The Yellow Birds. Gema Online Journal of Language Studies, $20 \quad$ (1), 139-150, doi.org/10.17576/gema-2020-2001-09.

[2] Crocq, M. A. \& L. Crocq. (March 2000). From shell shock and war neurosis to posttraumatic stress disorder: a history of psychotraumatology. Dialogues Clin Neurosci, 2 (1), 47-55.

[3] Emery, P.F.\& O. B. Emery. (1989). Psychoanalytic Considerations on PostTraumatic Stress Disorder. Journal of Contemporary Psychotherapy, 19 (1), 3953.

[4] Ferenczi, S., et al. (1921). Psychoanalysis and the War Neurosis. Ed. E. Jones. Vienna: The International-Psychoanalytical Press. 
[5] Freud, A. (1983). Problems of pathogenesis in the psychoanalytic study of the child, 38, 383-388). New Haven: Yale University Press.

[6] Freud, A. (1993). The Ego and the Mechanisms of Defence. London: Karnac Books.

[7] Freud, S. (1920/2015). Beyond the Pleasure Principle. New York: Dover Publications, Inc.

[8] Hawthorn, J. (2017). Studying the Novel. Ed. (7). London: Bloomsbury Academic.

[9] Perelberg, R. J., ed. (1999). Psychoanalytic Understanding of Violence and Suicide. London: Routledge.

[10] "Posttraumatic Stress Disorder (PTSD)". (n.d.). Accessed 6 Feb. 2021. American Psychiatric Association, <http://www.psychiatry.org>.

[11] Powers, K. The Yellow Birds. (2012/ 2013) New York: Little Brown and Company.

[12] Satriawan, F. Y. and M. Rahayu. (2020). “A Soldier's Post Traumatic Stress Disorder in Kevin Power's The Yellow Birds. Journal Pembelajaran Sastra, 2 (1), 1-11.

[13] Yacoub, G. (1999). Psychologiat al-Huroob and Dawr al-Ilaj al-Nafsi, Idtirab Doughout mabaadal-Sadma. Beirut: Dar al-Farabi.

\section{Endnote}

' Prof. Yacoub's book is written in Arabic, whatever quotes is the authors' translation 